University of Wollongong

Research Online

Faculty of Business - Papers (Archive)

Faculty of Business and Law

2013

Governance, media and the quality of environmental disclosure

Juergen Seufert

University of Wollongong, juergen@uow.edu.au

Follow this and additional works at: https://ro.uow.edu.au/buspapers

Part of the Business Commons

Research Online is the open access institutional repository for the University of Wollongong. For further information contact the UOW Library: research-pubs@uow.edu.au 


\title{
Governance, media and the quality of environmental disclosure
}

\author{
Abstract \\ Article review - Governance, Media and the Quality of Environmental Disclosure K. H. Rupley, D. Brown and \\ R. S. Marshall Journal of Accounting and Public Policy, 2012, 31 (6), pp. 610-640 \\ Keywords \\ media, environmental, quality, disclosure, governance \\ Disciplines \\ Business \\ Publication Details \\ Seufert, J. (2013). Governance, media and the quality of environmental disclosure. Social and \\ Environmental Accountability Journal, 33 (3), 183-184.
}


Governance, Media and the Quality of Environmental Disclosure

K. H. Rupley, D. Brown and R. S. Marshall

Journal of Accounting and Public Policy, 2012, 31 (6), pp. 610-640

Due to the increased importance of environmental disclosure and the significance of positive governance on the extent of information disclosure, Rupley, Brown and Marshall's (2012) study examines the relations between media coverage, specific governance attributes and the quality of voluntary environmental disclosure (VED). Based on a sample of 127 US firms over a 6-year period (2000-2005), the relation between media coverage and governance attributes in regard to VED is empirically tested.

Results indicate that negative media attention results in higher quality VED; and strong board characteristics have a positive impact on 'compliance' level disclosure. No relation was found between investor attributes (short- vs. long-term oriented) and VED-quality. Interaction between investor attributes and negative media is associated with higher disclosure. Negative media was also found to have an impact on the four board attribute variables leading to either higher or less disclosure. The longitudinal analysis reveals that over time reporting quality advances and consistency of these findings is supported throughout sensitivity analyses.

The authors suggest inclusion of board members' affiliations and audit committee involvement for further research. Also, the link of VED to outcomes such as cost of equity and other performance-related variables could be explored. The authors note as a limitation of the study that only US companies are included in the sample, which limits the generalisability to companies in other countries. The categorisation of the sample into three categories might also be overly simplistic. Reliance on only one media source (the Wall Street Journal) might create bias. Finally, endogeneity related to governance attributes and disclosure quality might exist.

Further research could go beyond the chosen timeframe of this study and investigate how VED(-quality) changed during the Global Financial Crisis. Also, further communication channels (e.g. Internet and press releases) used as a response to negative media could be included to increase the inclusiveness of companies' stakeholder communication (Aerts and Cormier 2009). Additional to VED, social disclosure and media attention and additional internal and external factors could be considered (Adams 2002; Deegan 2002). Future researchers might take into account that (annual) VED are not a timely response to negative media attention and companies might choose particular communication for particular stakeholders dependent on the particular event (Spence 2009).

References

Adams, C. A. 2002. "Internal Organisational Factors Influencing Corporate Social and Ethical Reporting: Beyond Current Theorizing." Accounting, Auditing \& Accountability Journal 15 (2): 223-250.

Aerts, W., and Cormier, D. 2009. "Media Legitimacy and Corporate Environmental Communication.” Accounting, Organizations and Society 34 (1): 1-27.

Deegan, C. 2002. "Introduction: The Legitimising Effect of Social and Environmental Disclosures - A Theoretical Foundation.” Accounting, Auditing \& Accountability Journal 15 (3): 282-311.

Spence, C. 2009. “Social and Environmental Reporting and the Corporate Ego.” Business Strategy and the Environment 18 (4): $254-265$.

Juergen H. Seufert

University of Wollongong, Australia

(C) 2013, Juergen H. Seufert

http://dx.doi.org/10.1080/0969160X.2013.845039 